\title{
Utjecaj obrade površine termoplastičnih poliolefina plamenom na adheziju premaza u industrijskim uvjetima robotskog bojenja
}

https://doi.org/10.15255/KUI.2020.072

KUI-34/2021

Izvorni znanstveni rad

Prispjelo 4. studenoga 2020.

Prihvaćeno 7. veljače 2021.

\author{
V. Merzel,a S. Lučić Blagojević,b Z. Buhin Šturlić, \\ M. Meheša i M. Leskovac b* \\ a AD PLASTIK d. d., Solin, PJ Zagreb \\ b Sveučilište u Zagrebu, Fakultet kemijskog inženjerstva i tehnologije, \\ Marulićev trg 19, 10000 Zagreb
}

\begin{abstract}
Sažetak
U ovom radu istražen je utjecaj obrade plamenom polipropilena (PP) i termoplastičnih poliolefina s talkom i čađom (TPO) na površinska svojstva i adheziju nanesenog premaza u uvjetima industrijskog procesa robotskog bojenja. Obrada plamenom provedena je na dvije udaljenosti plamena od površine $(7,5 \mathrm{~cm} \mathrm{i} 12,5 \mathrm{~cm})$ pri konstantnom protoku zraka i metana te brzini kretanja plamenika. Toplinska postojanost netretiranih uzoraka ispitana je primjenom termogravimetrijske analize (TGA). Promjena toplinskih svojstava prije i nakon obrade plamenom praćena je primjenom diferencijalne pretražne kalorimetrije (DSC). Metodom kontaktnog kuta određena je površinska energija uzoraka prije obrade plamenom te $1 \mathrm{~h}$ i $24 \mathrm{~h}$ nakon obrade plamenom. Promjene uzrokovane obradom plamenom istražene su ATR - FTIR analizom, a morfološke promjene pretražnim elektronskim mikroskopom (SEM). Nakon nanošenja temeljnog sloja, sloja boje i sloja laka na površinu obrađenih uzoraka određena je adhezija standardnim metodama ISO 2409 i ISO 16925/D25 2018-B. Rezultati su pokazali da TPO uzorci koji sadrže punilo talk i čađu imaju bolju toplinsku postojanost u odnosu na PP. Obrada plamenom utječe na promjenu površinskih karakteristika uzoraka, povećanje slobodne površinske energije i na izgled/strukturu površine. ATR - FTIR analizom utvrđeno je postojanje polarnih skupina na površini nakon obrade plamenom. Svi obojeni uzorci prema zahtjevima normi zadovoljavaju uvjete izvrsne adhezije na međupovršini supstrat/premaz.
\end{abstract}

Ključne riječi

Polipropilen, termoplastični poliolefini, obrada plamenom, slobodna površinska energija, premaz, adhezija

\section{Uvod}

Svojstva površine polimernog materijala definirana su kemijskom strukturom o kojoj najviše ovisi sposobnost ostvarivanja dobre adhezije između osnovnog premaza i supstrata. Kod polipropilena i termoplastičnih poliolefina površina je neporozna i kemijski inertna, nepolarne je prirode odnosno niske površinske energije. To je razlog slabog vlaženja, odnosno nemogućnosti ostvarivanja dobre adhezije s materijalima visoke površinske energije kao što su osnovni premazi, bilo na uljnoj ili vodenoj osnovi. Preduvjet za dobru adheziju između polimera i premaza jest dobro vlaženje, što u konačnici rezultira dobrim uporabnim svojstvima obojenog proizvoda.

Priprema poliolefinskih materijala za bojenje zasniva se na obradi površine s ciljem promijene kemijske strukture površinskog sloja ${ }^{1-3}$ tj. povećanja udjela polarnih skupina. Kod polipropilenskih proizvoda debelih stjenki često se primjenjuje metoda obrade površine plamenom. U usporedbi s drugim metodama, obrada plamenom ima brojne praktične prednosti, uključujući kratko vrijeme trajanja postupka, znatno povećanje slobodne površinske energije i dulje vrijeme aktivnosti površine nakon obrade. Kad se polimer izloži izravnom plamenu, na površini se stvara velik broj polarnih skupina koje sadrže kisik. ${ }^{3-5}$ Proces gorenja obuhvaća niz složenih reakcija slobodnih radikala iz

${ }^{*}$ Autor za dopisivanje: prof. dr. sc. Mirela Leskovac

E-pošta: mlesko@fkit.hr plamena čiji mehanizam ni danas u potpunosti nije razjašnjen. Nizom reakcija slobodnih radikala iz plamena i polipropilenskih lanaca nastaju polarne hidroksilne, karboksilne i karbonilne skupine, što znatno utječe na povećanje prianjanja premaza na supstrat. ${ }^{6} \mathrm{~S}$ obzirom na morfologiju polimera, poliolefini koji imaju veći udio amorfne faze osjetljiviji su na obradu plamenom.

Da bi se osigurala pravilna udaljenost plamena od proizvoda, potrebno je poznavanje osnovnih zona laminarnog plamena (slika 1). Tri su glavne zone sagorijevanja u pla-

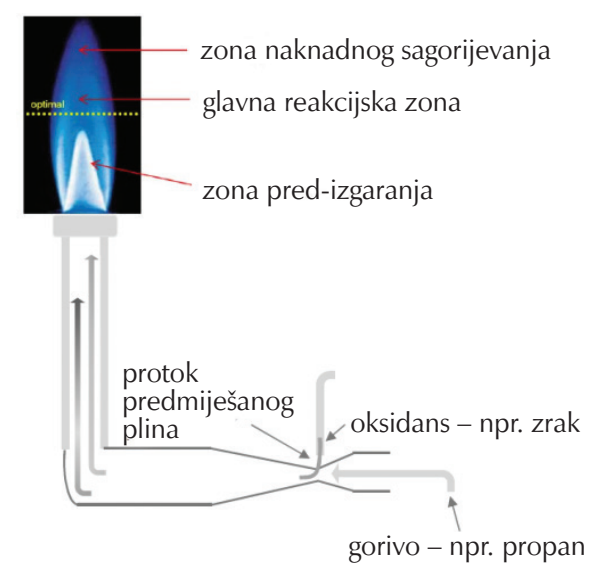

Slika 1 - Glavne zone laminarnog profila plamena ${ }^{6}$ Fig. 1 - Main zones of the laminar flame profile ${ }^{6}$ 
menu: zona predizgaranja, glavna reakcijska zona i zona naknadnog sagorijevanja. Temperatura plamena definirana je temperaturom u 1. i 2. zoni. U plavoj zoni (naknadnog sagorijevanja) zbog nedostatka slobodnih radikala za podržavanje reakcije gorenja, temperatura je niža u odnosu na drugu zonu. $U$ drugoj zoni odvija se glavnina reakcija koje omogućuju gorenje te je količina slobodnih radikala najveća.

Učinak obrade plamenom definiran je trima kontrolnim varijablama. Prva varijabla, omjer kisik : plin (npr. metan, propan, pentan) najvažnija je varijabla koja zahtijeva strogu kontrolu kako bi se osigurala postojanost postupka obrade plamenom. Gorenje metana može se prikazati sljedećom reakcijom:

$$
\mathrm{CH}_{4}+2 \mathrm{O}_{2} \rightarrow \mathrm{CO}_{2}+2 \mathrm{H}_{2} \mathrm{O} \text {. }
$$

Volumen zraka (kisika) potrebnog za izgaranje metana moguće je izračunati prema jedn. 1. Plamen koji ima višak zraka zove se oksidirajući plamen, a onaj s nedovoljno zraka reducirajući plamen. Drugu varijablu, vrijeme kontakta nužno je kontrolirati radi postizanja optimalnog učinka obrade. Ta varijabla definirana je brzinom prolaska materijala ispred plamena i ovisi o širini otvora plamenika, toplini sagorijevanja plina i vrsti materijala. Treća varijabla, udaljenost površine materijala od otvora plamena mora biti takva da površina nikada ne dolazi u kontakt s plavom zonom plamena. To područje je zona reducirajućeg plamena koje u tom slučaju poništava utjecaj obrade oksidirajućim plamenom.
Cilj ovog rada bio je istražiti utjecaj obrade površine plamenom na površinska svojstva polipropilena i termoplastičnih poliolefina modificiranih talkom i čađom kao punilom, u ovisnosti o udaljenosti plamena od površine proizvoda automobilske industrije. Budući da se $u$ industrijskim procesima obrada plamenom primjenjuje za aktivaciju površine polimera s ciljem poboljšanja adhezije na međupovršini supstrat/premaz, istražena je adhezija premaza na supstratu prethodno obrađenim plamenom.

\section{Eksperimentalni dio}

\subsection{Materijali}

Za pripremu automobilskih dijelova injekcijskim prešanjem upotrijebljen je granulat polipropilena (PP) (A) i tri vrste termoplastičnog poliolefina (TPO) na osnovi polipropilena s punilom talkom i čađom (B - D) (tablica 1).

\subsection{Priprema uzoraka i proces obrade plamenom}

Automobilski dijelovi pripravljeni su postupkom injekcijskog prešanja na proizvodnoj liniji tvornice AD Plastik d.d. pri uvjetima prikazanim u tablici 2, koji se primjenjuju u komercijalnoj proizvodnji za pojedine dijelove.

Površina automobilskih dijelova podvrgnuta je robotskoj obradi plamenom u realnom procesu koji osigurava pouzdane i konstantne uvjete bez obzira na oblik proizvo-

Tablica 1 - Materijali

Table 1 - Materials

\begin{tabular}{c|l|c|c|c|c|c}
\hline $\begin{array}{c}\text { Oznaka uzorka } \\
\text { Sample mark }\end{array}$ & $\begin{array}{c}\text { Naziv materijala } \\
\text { Material name }\end{array}$ & $\begin{array}{c}\text { Vrsta } \\
\text { Type }\end{array}$ & $\begin{array}{c}\text { Udio talka } \% \\
\text { Talc content } \%\end{array}$ & $\begin{array}{c}\text { Udio čađe } \% \% \\
\text { Char content } \%\end{array}$ & MFR*/g/10 min & $\begin{array}{c}\text { Proizvođač } \\
\text { Manufacturer }\end{array}$ \\
\hline A & Sabic 108MF10 & PP & 0 & 0 & 10 & Sabic \\
\hline B & Daplen EF 150 & TPO & 15 & 2 & 22 & Boreallis \\
\hline C & Daplen EG 107 HP & TPO & 12 & 2 & 22 & Boreallis \\
\hline D & Exxtral BMV 215 & TPO & 15 & 2 & 34 & Exxon Mobile \\
\hline
\end{tabular}

*MFR - indeks tečenja taline (engl. melt flow rate) prema ISO $1133-1\left(230{ }^{\circ} \mathrm{C} / 2,16 \mathrm{~kg}\right)$

Tablica 2 - Uvjeti brizganja automobilskih dijelova u procesu proizvodnje

Table 2 - Injection moulding conditions for automotive parts in the manufacturing process

\begin{tabular}{|c|c|c|c|c|c|c|}
\hline \multirow[b]{2}{*}{$\begin{array}{l}\text { Uzorak } \\
\text { Sample }\end{array}$} & \multirow[b]{2}{*}{$\begin{array}{l}\text { Proizvod iz procesa } \\
\text { Process product }\end{array}$} & \multirow[b]{2}{*}{$\begin{array}{c}\text { Stroj/sila zatvaranja } \\
\text { / kN } \\
\text { Machine/closing } \\
\text { force } / \mathrm{kN}\end{array}$} & \multicolumn{4}{|c|}{ Parametri injekcijskog prešanja / Injection pressing parameters } \\
\hline & & & $\begin{array}{c}\text { Temperatura } \\
\text { cilindra } /{ }^{\circ} \mathrm{C} \\
\text { Cylinder } \\
\text { temperature } /{ }^{\circ} \mathrm{C}\end{array}$ & $\begin{array}{c}\text { Tlak } \\
\text { prešanja/MPa } \\
\text { Pressing } \\
\text { pressure/MPa }\end{array}$ & $\begin{array}{c}\text { Brzina } \\
\text { prešanja } / \mathrm{mm} \mathrm{s}^{-1} \\
\text { Pressing } \\
\text { speed } / \mathrm{mm} \mathrm{s}^{-1}\end{array}$ & $\begin{array}{c}\text { Temperatura } \\
\text { kalupa } \mathrm{N} / \mathrm{P}^{*} /{ }^{\circ} \mathrm{C} \\
\text { Mould } \\
\text { temperature } /{ }^{\circ} \mathrm{C}\end{array}$ \\
\hline $\mathrm{AU}$ & Clio 4, ZO & ES2300/230 & 250 & 16 & 40 & $18 / 18$ \\
\hline BU & R4S, capot & KM3200/270 & 245 & 10 & 35 & $18 / 18$ \\
\hline $\mathrm{CU}$ & $\mathrm{R} 4 \mathrm{~S}, \mathrm{ZO}$ & ES3200/240 & 250 & 13 & 37 & $32 / 30$ \\
\hline DU & S4S, maska ZO & ES1700/150 & 230 & 12 & 35 & $30 / 18$ \\
\hline
\end{tabular}

${ }^{*} \mathrm{~N} / \mathrm{P}$ - nepokretna/pokretna strana alata 
da. Prije početka obrade površina je očišćena izopropilnim alkoholom a zatim tretirana deioniziranim zrakom. Obrada površine plamenom provedena je pomoću robota na temperaturi reakcijske zone metanskog plamena, pri čemu je protok metana bio $42 \mathrm{dm}^{3} \mathrm{~min}^{-1}$, protok zraka $420 \mathrm{dm}^{3} \mathrm{~min}^{-1}$ (volumni omjer zrak/metan $=10 / 1$ ) te brzina linije za obradu plamenom $550 \mathrm{~mm} \mathrm{~s}^{-1}$. Proces obrade plamenom proveden je pri dvjema različitim udaljenostima plamena od površine 7,5 cm i 12,5 cm. Oznake neobrađenih i plamenom obrađenih dijelova prikazane su u tablici 3.

Tablica 3 - Oznake automobilskih dijelova prije i nakon obrade plamenom

Table 3 - Designation of automotive parts before and after flame treatment

\begin{tabular}{c|c|c}
\hline $\begin{array}{c}\text { Prešani dijelovi } \\
\text { (neobrađeni) }\end{array}$ & \multicolumn{2}{|c}{$\begin{array}{c}\text { Udaljenost plamena/cm } \\
\text { Flame distance } / \mathrm{cm}\end{array}$} \\
$\begin{array}{c}\text { Pressed parts } \\
\text { (untreated) }\end{array}$ & 7,5 & 12,5 \\
\hline $\mathrm{AU}$ & $1 \mathrm{AU}$ & $2 \mathrm{AU}$ \\
\hline $\mathrm{BU}$ & $1 \mathrm{BU}$ & $2 \mathrm{BU}$ \\
\hline $\mathrm{CU}$ & $1 \mathrm{CU}$ & $2 \mathrm{CU}$ \\
\hline $\mathrm{DU}$ & $1 \mathrm{DU}$ & $2 \mathrm{DU}$ \\
\hline
\end{tabular}

Na pogodnim mjestima iz prešanih i plamenom obrađenih automobilskih dijelova izrezani su uzorci u obliku pločica dimenzija $150 \mathrm{~mm} \times 100 \mathrm{~mm}$ iz kojih su potom izuzimani ispitci odgovarajućih dimenzija ili masa za pojedine analize.

\subsection{Karakterizacija uzoraka prije i nakon obrade plamenom}

\subsubsection{Termogravimetrijska analiza (TGA)}

Toplinska postojanost i udio nerazgradivog ostatka ishodnih uzoraka prije obrade plamenom AU - DU određeni su termogravimetrijskom analizom (TGA) na instrumentu TA Instruments Q500. Mjerenja su provedena u temperaturnom području od 25 do $900{ }^{\circ} \mathrm{C}$ pri brzini zagrijavanja od $10^{\circ} \mathrm{C} \mathrm{min}^{-1}$, u inertnoj atmosferi dušika uz protok $60 \mathrm{~cm}^{3} \mathrm{~min}^{-1}$. Masa uzorka iznosila je $10 \pm 0,2 \mathrm{mg}$.

\subsubsection{Diferencijalna pretražna kalorimetrija (DSC)}

Toplinska svojstva uzoraka prije i nakon obrade plamenom (tablica 3) određena su na instrumentu DCS $823^{e}$ proizvođača Mettler Toledo. Instrument je opremljen jedinicom za automatsko reguliranje protoka dušika prema zadanoj eksperimentalnoj metodi. Mjerenja su provedena u aluminijskim DSC posudicama volumena $40 \mu \mathrm{l}$ proizvođača Netch. Instrument je kalibriran indijem prema standardnoj proceduri koja je sastavni dio računalnog paketa DSC instrumenta. Masa svih uzoraka iznosila je 10 $\pm 0,2 \mathrm{mg}$. DSC analiza provedena je postupkom u tri ciklusa kako slijedi. $\mathrm{U}$ prvom ciklusu provedeno je hlađenje od $25{ }^{\circ} \mathrm{C}$ do $0{ }^{\circ} \mathrm{C}$ brzinom $10{ }^{\circ} \mathrm{C} \mathrm{min}^{-1}$. U drugom ciklusu provedena je izo- termna stabilizacija pri $0{ }^{\circ} \mathrm{C}$ u trajanju od $2 \mathrm{~min}$, a potom je u trećem ciklusu uzorak zagrijavan od $0{ }^{\circ} \mathrm{C}$ do $200{ }^{\circ} \mathrm{C}$ brzinom $10{ }^{\circ} \mathrm{C} \mathrm{min}^{-1}$. Svi ciklusi provedeni su u inertnoj struji dušika od $50 \mathrm{~cm}^{3} \mathrm{~min}^{-1}$. Analizirani su termogrami ciklusa zagrijavanja.

\subsubsection{ATR - FTIR analiza}

FTIR spektri uzoraka prije i nakon obrade plamenom snimljeni su pomoću Perkin Elmer Spectrum One Spectrometer, primjenom prigušene totalne refleksije $s$ jednim odrazom (engl. Single Reflection ATR System), sa ZnSe kristalom. Mjerenja su provedena u području valnih duljina od 650 do $4000 \mathrm{~cm}^{-1}$, pri rezoluciji $4 \mathrm{~cm}^{-1}$. Prikazani spektri (slika 3) rezultat su četiriju uzastopnih mjerenja.

\subsubsection{Određivanje slobodne površinske energije}

Slobodna površinska energija uzoraka prije i nakon obrade plamenom određena je tehnikom mjerenja kontaktnog kuta na uređaju DataPhysics OCA 20 Instruments $\mathrm{GmbH}$. Za određivanje kontaktnog kuta upotrijebljene su testne kapljevine, voda, formamid i dijodometan, poznatih vrijednosti slobodne površinske energije (tablica 4).

Tablica 4 - Komponente slobodne površinske energije testnih kapljevina ${ }^{7,8}$

Table 4 - Test liquids' surface free energy components ${ }^{7,8}$

\begin{tabular}{c|c|c|c}
\hline \multirow{2}{*}{$\begin{array}{c}\text { Testna kapljevina } \\
\text { Test liquid }\end{array}$} & \multicolumn{3}{|c}{$\begin{array}{c}\text { Slobodna površinska energija } / \mathrm{mJ} \mathrm{m}^{-2} \\
\text { Surface free energy } / \mathrm{m}^{-2} \mathrm{~m}^{-2}\end{array}$} \\
\cline { 2 - 4 } & $\gamma$ & $\gamma^{\mathrm{d}}$ & $\gamma^{\mathrm{p}}$ \\
\hline voda & 72,8 & 21,8 & 51,0 \\
\hline formamid & 58,0 & 39,0 & 19,0 \\
\hline dijodometan & 50,8 & 50,8 & 0,0 \\
\hline
\end{tabular}

Volumen kapi testnih kapljevina iznosio je $2 \mu \mathrm{l}$. Srednja vrijednost kontaktnog kuta za pojedinu testnu kapljevinu dobivena je na osnovi mjerenja 10 - 15 kapljica. Odstupanja rezultata od srednje vrijednosti iznosila su $\pm 3^{\circ}$. Mjerenja kontaktnog kuta provedena su $1 \mathrm{~h}$ i 24 h nakon obrade površine uzoraka plamenom. Slobodna površinska energija ispitivanih uzoraka proračunata je pomoću računalnog programa SCA 20 (Version 2.01, Data Physics Instruments, $\mathrm{GmbH}$, 2001.), primjenom dvoparametarskog modela harmonijske sredine. Model harmonijske sredine (jedn. 2) koji je razvio $W^{7}$ primjenjuje se za površine niske slobodne površinske energije kao što su polimeri.

$$
\gamma_{\mathrm{lv}}(1+\cos \theta)=\frac{4 \gamma_{\mathrm{s}}^{\mathrm{d}} \gamma_{1}^{\mathrm{d}}}{\gamma_{\mathrm{s}}^{\mathrm{d}}+\gamma_{1}^{\mathrm{d}}}+\frac{4 \gamma_{\mathrm{s}}^{\mathrm{p}} \gamma_{1}^{\mathrm{p}}}{\gamma_{\mathrm{s}}^{\mathrm{p}}+\gamma_{1}^{\mathrm{p}}}
$$

gdje su $\gamma_{\mathrm{Iv}}$ ukupna slobodna površinska energija testne kapljevine, $\gamma_{1}^{d}$ i $\gamma_{1}^{p}$ disperzna i polarna komponenta površinske energije testne kapljevine, $\gamma_{s}^{\mathrm{d}} \mathrm{i} \gamma_{s}^{\mathrm{p}}$ disperzna i polarna komponenta površinske energije ispitivanog uzorka, a $\theta$ kontaktni kut. 
Određivanje površinske energije primjenom standardnih flomastera često se primjenjuje za brzo testiranje površinske energije $u$ industriji. Ispitivanja su provedena s testnim flomasterima proizvođača Hill, $\mathrm{GmbH}$, različitih površinskih energija 38, 40, 42, 44, 46, 48 i 50 mJ m². Ispitivanja flomasterima vrlo su jednostavna i brza, a provode se iscrtavanjem linije na površini koja se ispituje. Ispitivanja se provode s tintama različite površinske energije, a površinska energija supstrata odgovara onoj površinskoj energiji tinte koja ostaje u obliku povučene linije odnosno ne sužava se niti formira kapljice na površini uzorka u vremenu od 1 do 2 s.

\subsubsection{Pretražna elektronska mikroskopija (SEM)}

Morfologija površine neobrađenih i plamenom obrađenih PP i TPO uzoraka dimenzija $10 \mathrm{~mm} \times 10 \mathrm{~mm}$ analizirana je na QUANTA FEG 250SEM FEI pretražnom elektronskom mikroskopu s emisijom polja i OXFORD PENTA FET EDS detektorom, pri povećanju 3000 puta. Na tom uređaju prije postavljanja u komoru uzorke nije potrebno prevlačiti vodljivim materijalom. Uzorci su snimani pri optimalnim parametrima za polimerne materijale odnosno radnoj duljini fokusa 8 - $10 \mathrm{~mm}$, veličini točke (engl. spot size) 5, naponu od $20 \mathrm{kV}$ te primjenom detektora niskog vakuuma (engl. low vacuum detector).

\subsection{Postupak bojenja}

Postupak bojenja površine automobilskih dijelova nakon procesa obrade plamenom proveden je elektrostatskim raspršivanjem pomoću aplikatora s rotacijskim zvonom u tri sloja. Najprije je nanesen temeljni sloj sredstva za vezivanje. Nakon 14 min nanesen je sloj boje, a nakon 10 min nanesen je završni sloj laka. Sloj laka sušen je 10 min pri $23{ }^{\circ} \mathrm{C}$, a umreženje laka postignuto je sušenjem u komori u vremenu od $45 \mathrm{~min}$ pri temperaturi $85^{\circ} \mathrm{C}$.

\subsection{Ispitivanje adhezije obojenih uzoraka}

Iz obojenih automobilskih dijelova izrezane su pločice dimenzija $150 \mathrm{~mm} \times 100 \mathrm{~mm}$ koje su podvrgnute ispitivanju adhezije premaza zarezivanjem mrežice (engl. cross cut test) i nakon 7 dana od procesa bojenja ispitivanju pranja pod visokim tlakom.

Ispitivanje adhezije premaza zarezivanjem mrežice provedeno je prema normi ISO 2409. ${ }^{9}$ Ispitivanja su provedena pri temperaturi $23 \pm 2{ }^{\circ} \mathrm{C}$ i relativnoj vlažnosti $50 \pm 5 \%$. Obojena pločica postavlja se na čvrstu i ravnu podlogu te se nožem (Erichsen, Model $n^{\circ} 295 /$ II) sa 6 oštrica između kojih je $2 \mathrm{~mm}$ razmaka (Erichsen, Model $\mathrm{n}^{\circ} 295 / \mathrm{II}$ ) okomito zarezuje mreža u obliku kvadrata $10 \mathrm{~mm} \times 10 \mathrm{~mm}$ kroz premaz sve do površine supstrata. Nakon zarezivanja, mekanom četkom uklone se nastale niti. Adhezija premaza ispituje se ljepljivom trakom, koja se postavlja preko mreže u smjeru usporednom s jednim potezom zareza i pričvrsti dodatnim utiskivanjem prstom te ostavi stajati 5 min. Nužno je da zalijepljeni dio trake prelazi mrežu najmanje $20 \mathrm{~mm}$. Povlačenjem slobodnog kraja ljepljive trake pod kutom od oko $60^{\circ} \mathrm{u}$ vremenu od $1 \mathrm{~s}$ skine se traka. Nakon skidanja ljepljive trake uspoređuje se izgled zarezane mreže sa skalom navedenom u normi, prema kojoj se izgled površine ocjenjuje s 0 do 5. Izgled površine koji odgovara ocjenama 0 i 1 predstavlja izvrsnu i vrlo dobru adheziju premaza s površinom supstrata, dok ocjene od 2 do 5 označavaju lošu adheziju različitog stupnja odvajanja premaza od supstrata, od $5 \%$ do $65 \%$ površine.

Ispitivanje adhezije pranjem pod visokim tlakom (PVT) provedeno je prema normi ISO 16925 /D25 2018-B ${ }^{10}$ na uređaju Walter Cleaning Systems - LTA1 Steam Jet tester pri okomitom položaju mlaznica. Prije ispitivanja obojeni uzorci su kondicionirani 7 dana pri sobnoj temperaturi. Uzorak se učvrsti te se nožićem pomoću šablone u obliku slova X okomito zarezuje premaz do površine supstrata. Ispitivanja pranja pod visokim tlakom provedena su u vremenu od $30 \pm 2 \mathrm{~s}$, pri tlaku od 6,5 $\mathrm{MPa}$, temperaturi od $70 \pm 10{ }^{\circ} \mathrm{C}$, protoku vode od $720 \mathrm{dm}^{3} \mathrm{~h}^{-1} \mathrm{i}$ udaljenosti mlaznice $100 \mathrm{~mm}$ od površine. Nakon pranja utvrđuje se je li došlo do odvajanja (ljuštenja) premaza od supstrata. Kategorija oljuštene površine utvrđuje se kao prihvatljiva ako je ta površina uzduž zareza $\leq 1 \mathrm{~mm}^{2} \mathrm{i} \leq 10 \mathrm{~mm}^{2}$ na vrhovima ili centru križa.

\section{Rezultati i rasprava}

\subsection{Toplinska postojanost ishodnih uzoraka}

Termogravimetrijskom analizom ispitana je toplinska postojanost i udio nerazgradivog ostatka u PP i TPO uzorcima (AU - DU). Toplinska postojanost materijala procijenjena je temeljem značajki dobivenih iz TG i DTG krivulja; $T_{5}$ - temperatura pri $5 \%$ gubitka mase, $T_{50}$ - temperatura pri $50 \%$ gubitka mase, $T_{\text {end set }}$ - temperatura maksimalnog gubitka mase, $T_{\max }$ - temperatura maksimalne brzine razgradnje, $\Delta T$ - temperaturni raspon razgradnje $\left(T_{\text {end set }}-T_{5}\right)$. Primjer TG i DTG krivulja uzoraka AU i BU prikazani su na slici 2, a rezultati svih ispitivanih uzoraka dani su u tablici 5.

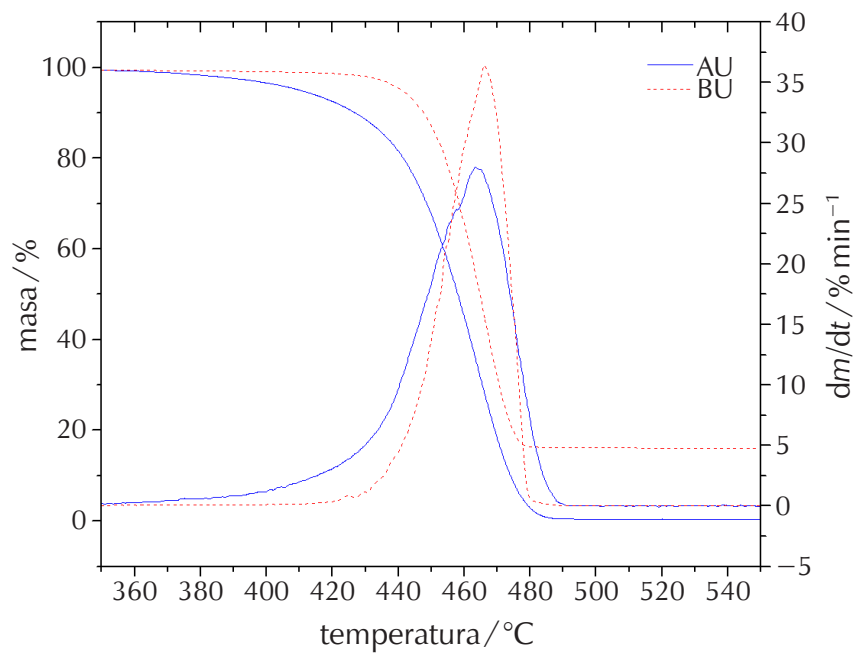

Slika 2 - TG i DTG krivulje uzoraka AU i BU

Fig. 2 - TG i DTG curves of samples AU and BU 
Tablica 5 - Rezultati termogravimetrijske analize

Table 5 - Results of thermogravimetric analysis

\begin{tabular}{c|c|c|c|c|c|c}
\hline \multirow{2}{*}{$\begin{array}{c}\text { Uzorak } \\
\text { Sample }\end{array}$} & \multicolumn{4}{|c|}{ TG } & \multicolumn{2}{c}{ DTG } \\
\cline { 2 - 7 } & $T_{5} /{ }^{\circ} \mathrm{C}$ & $T_{50} /{ }^{\circ} \mathrm{C}$ & $T_{\text {end set }} /{ }^{\circ} \mathrm{C}$ & $\begin{array}{c}\text { Ostatak } / \% \\
\text { Residue } / \%\end{array}$ & $T_{\max } /{ }^{\circ} \mathrm{C}$ & $\Delta T /{ }^{\circ} \mathrm{C}$ \\
\hline $\mathrm{AU}$ & 410 & 458 & 478 & 0,4 & 463 & 68 \\
\hline $\mathrm{BU}$ & 441 & 465 & 475 & 15,0 & 466 & 34 \\
\hline $\mathrm{CU}$ & 434 & 468 & 480 & 15,3 & 467 & 46 \\
\hline $\mathrm{DU}$ & 437 & 470 & 481 & 14,9 & 472 & 44 \\
\hline
\end{tabular}

Razgradnja PP uzorka (AU) i TPO uzoraka (BU - DU) odvija se u jednom stupnju. Toplinska razgradnja polipropilena odvija se mehanizmom statističkog cijepanja polimernih lanaca nakon čega slijedi proces prijenosa radikala. Kao glavni produkti toplinske razgradnje polipropilena nastaju pentan, 2-metil-1-penten i 2,4-dimetil-1-hepten. Navedeni procesi odvijaju se istodobno, što rezultira jednim razgradim stupnjem na TG krivulji i jednim maksimumom na DTG krivulji. ${ }^{11}$ Uzorak polipropilena AU koji ne sadrži punilo razgrađuje se $\mathrm{u}$ širem rasponu temperatura $(\Delta T=$ $68{ }^{\circ} \mathrm{C}$ ), dok se uzorci BU, CU i DU koji sadrže punilo razgrađuju u užem rasponu temperatura $\left(\Delta T=34-46^{\circ} \mathrm{C}\right)$. Također je vidljivo da početak razgradnje, $\left(T_{5}\right)$ uzorka $\mathrm{AU}$, počinje pri nižim temperaturama (za $24-30^{\circ} \mathrm{C}$ ) u odnosu na uzorke s punilom (talk, čađa) BU, CU i DU. I druge karakteristične temperature razgradnje $\left(T_{50}, T_{\max }, T_{\text {end set }}\right)$ niže su za uzorak AU u odnosu na uzorke BU - DU. Iz dobivenih rezultata vidljivo je da dodatak talka i čađe poboljšava toplinsku postojanost poliolefina. Taj učinak pripisuje se slojevitoj strukturi talka, koji sprječava izlaz razgradnih produkata iz uzorka, te na taj način usporava razgradnju. ${ }^{12}$

Uzorak AU pri $900{ }^{\circ} \mathrm{C}$ ima malu količinu ostatka nakon razgradnje 0,43 mas.\%, dok uzorci BU, CU i DU koji sadrže punilo talk i čađu imaju znatno viši ostatak (tablica 5), koji odgovara količini anorganske faze.

\subsection{Rezultati DSC analize}

DSC analizom ispitana su toplinska svojstva uzoraka prije i nakon obrade plamenom na udaljenosti $7,5 \mathrm{~cm}$ i $12,5 \mathrm{~cm}$. Rezultati entalpija i temperatura taljenja kristalne faze prikazani su u tablici 6.

$U$ ciklusu zagrijavanja uzorka $\mathrm{AU}$ te uzoraka obrađenih plamenom 1AU i $2 A U$ na DSC krivulji vidljiva je endoterma promjena koja odgovara taljenju kristalne faze pri temperaturi $112 \pm 2{ }^{\circ} \mathrm{C}$ te glavni endoterm pri $169 \pm 1{ }^{\circ} \mathrm{C}$. DSC krivulje uzoraka iz serija od BU do DU pokazuju endotermne promjene koje se nalaze na temperaturi drugog endoterma uzoraka iz AU serije. Uočene razlike mogu se pripisati razlikama u formulaciji materijala ili učinku talka na kristalizaciju matrice pa time posljedično i na taljenje kristalne faze.

Rezultati za sve uzorke pokazuju da ne postoji znatan učinak obrade plamenom na temperaturu taljenja $\left(T_{\mathrm{m}}=169 \pm 1{ }^{\circ} \mathrm{C}\right)$, što upućuje na to da proces obrade
Tablica 6 - Rezultati DSC analize uzoraka prije i nakon obrade plamenom

Table 6 - Results of DSC analysis for samples before and after flame treatment

\begin{tabular}{c|c|c|c|c}
\hline \multirow{2}{*}{$\begin{array}{c}\text { Uzorak } \\
\text { Sample }\end{array}$} & \multicolumn{2}{|c|}{$\begin{array}{c}\text { 1. endoterm } \\
1^{\text {st }} \text { endotherm }\end{array}$} & \multicolumn{2}{c}{$\begin{array}{c}\text { 2. endoterm } \\
2^{\text {nd }} \text { endotherm }\end{array}$} \\
\cline { 2 - 5 } & $\Delta H_{\mathrm{m}} / \mathrm{Jg}^{-1}$ & $T_{\mathrm{m}} /{ }^{\circ} \mathrm{C}$ & $\Delta H_{\mathrm{m}} / \mathrm{Jg}^{-1}$ & $T_{\mathrm{m}} /{ }^{\circ} \mathrm{C}$ \\
\hline $\mathrm{AU}$ & 1,4 & 113 & 64,2 & 169 \\
\hline $1 \mathrm{AU}$ & 2,7 & 111 & 64,9 & 170 \\
\hline $2 \mathrm{AU}$ & 1,8 & 114 & 68,5 & 169 \\
\hline $\mathrm{BU}$ & $/$ & $/$ & 51,7 & 169 \\
\hline $1 \mathrm{BU}$ & $/$ & $/$ & 55,1 & 168 \\
\hline $2 \mathrm{BU}$ & $/$ & $/$ & 54,8 & 168 \\
\hline $\mathrm{CU}$ & $/$ & $/$ & 54,3 & 170 \\
\hline $1 \mathrm{CU}$ & $/$ & $/$ & 57,5 & 169 \\
\hline $2 \mathrm{CU}$ & $/$ & $/$ & 58,1 & 169 \\
\hline $\mathrm{DU}$ & $/$ & $/$ & 52,3 & 169 \\
\hline $1 \mathrm{DU}$ & $/$ & $/$ & 51,5 & 169 \\
\hline $2 \mathrm{DU}$ & $/$ & $/$ & 50,3 & 168 \\
\hline
\end{tabular}

plamenom ne utječe na uređenost kristalne strukture ili debljinu kristalnih lamela. Obradom plamenom entalpija taljenja se ne mijenja ili se mijenja neznatno. Za uzorke u kojima dolazi do promjene entalpija taljenja raste za najviše $4 \mathrm{~J} \mathrm{~g}^{-1}$, što je mala promjena s obzirom na ukupnu entalpiju. Za uzorak AU porast se uočava samo za uzorak obrađen na udaljenosti $12,5 \mathrm{~cm}$ (2AU). Uzorci 1BU, 2BU, $1 C U$ i $2 \mathrm{CU}$ imaju više vrijednosti entalpija u odnosu na neobrađene uzorke BU i CU. Za uzorke 1DU i 2DU nema promjene u odnosu na DU uzorak bez obzira na udaljenost plamena tijekom obrade. Iz dobivenih rezultata ne može se uočiti jednoznačan učinak udaljenosti plamena od površine uzorka na promjenu entalpije taljenja. Dobiveni rezultati mogu se objasniti činjenicom da tijekom obrade plamenom dolazi do porasta temperature samo površinskog sloja uzorka, što ne uzrokuje znatne promjene u kristalnoj strukturi materijala.

\subsection{Kvalitativna kemijska analiza površine}

Na FTIR spektrima uzoraka polipropilena (AU) i termoplastičnih poliolefina (BU, CU, DU) nakon obrade plamenom vidljive su razlike $u$ području valnih brojeva $1500-1800 \mathrm{~cm}^{-1}$. Primjer ATR spektara uzorka AU prije i nakon obrade plamenom, $1 \mathrm{AU}$ i $2 \mathrm{AU}$, prikazani su na slici 3. lako su promjene transmitancije u tom području relativno slabe (slika 3a), one upućuju na nastajanje funkcionalnih skupina koje sadrže kisik, a posljedica su procesa obrade plamenom. Za sve uzorke nakon obrade plamenom u području valnih brojeva $1500-1800 \mathrm{~cm}^{-1}$ javljaju se dvije vrpce; vrpca I između 1630 i $1650 \mathrm{~cm}^{-1}$ i vrpca II između $1720-1740 \mathrm{~cm}^{-1}$, kao što je prikazano primjerom na slici 3b za uzorke 1AU i $2 A U$. Da bi se bolje uočile razlike između FTIR spektara, krivulje (pune linije) su dodatno opisane krivuljama prosječnih vrijednosti uzetih iz 

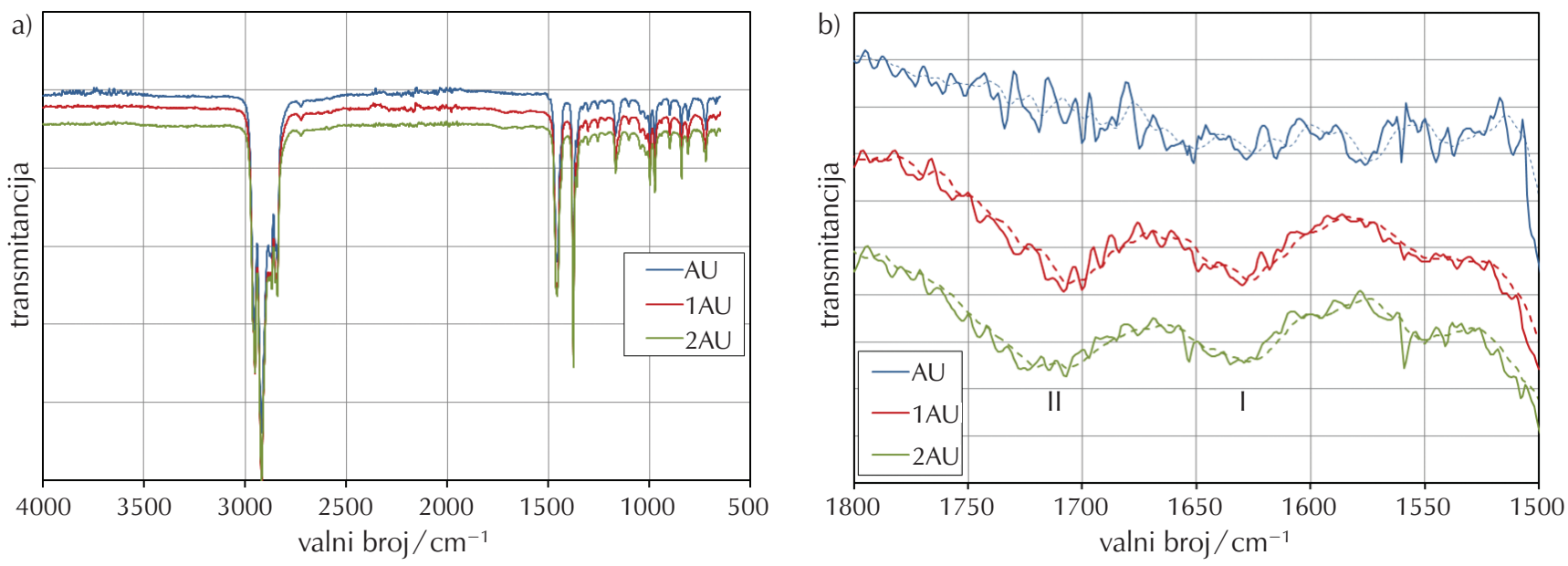

Slika 3 - a) FTIR spektri uzorka prije (AU) i uzoraka nakon obrade plamenom (1AU i 2AU). b) Porast transmitancije u području valnih brojeva $1750-1600 \mathrm{~cm}^{-1}$

Fig. 3 - a) FTIR spectra of sample before (AU) and samples after flame treatment (1AU and $2 A U)$. b) Increase in transmittance at range of wave numbers $1750-1600 \mathrm{~cm}^{-1}$

svakih 10 točaka (crtkane linije). Pojava vrpce I povezuje se $\mathrm{s}$ nastajanjem karbonilnih $>\mathrm{C}=\mathrm{O}$ skupina (valentne vibracije) kao i $-\mathrm{C}=\mathrm{C}$ - skupina. ${ }^{13}$ Pojava vrpce II odgovara karbonilnim skupinama koje nastaju oksidacijom kao rezultat nukleofilne supstitucije, uglavnom na tercijarnom ugljikovu atomu polipropilena. Cinjenica da je vrpca II relativno široka može upućivati na prisutnost karbonilne skupine u različitim produktima oksidacije kao što su aldehidne i ketonske skupine: $1700 \mathrm{~cm}^{-1}(>\mathrm{C}=\mathrm{CH}-\mathrm{CO}-\mathrm{OH})$, $1710 \mathrm{~cm}^{-1}(-\mathrm{CO}-\mathrm{OH}), 1715 \mathrm{~cm}^{-1}$, $(>\mathrm{C}=\mathrm{O}), 1718 \mathrm{~cm}^{-1}\left(-\mathrm{CCH}_{3}-\mathrm{CH}_{2} \mathrm{CO}-\right.$ $\left.\mathrm{CH}_{2}-\mathrm{CH}_{3}\right) .{ }^{13}$ Osim tih skupina u području vrpce II navode se $>\mathrm{C}=\mathrm{O}$ vibracije u esterskim skupinama na $1735 \mathrm{~cm}^{-1} .{ }^{14}$ Prema dobivenima rezultatima očito je da proces obrade plamenom bez obzira na udaljenost $(7,5 \mathrm{~cm}$ ili $12,5 \mathrm{~cm})$ utječe na nastajanje polarnih skupina na površini uzorka. S obzirom na to da je intenzitet vrpci I i II mali, nije moguće kvantitativno odrediti učinak obrade plamenom.

\subsection{Slobodna površinska energija}

Karakterizacija površine uzoraka PP i TPO prije i nakon obrade plamenom na udaljenosti od $7,5 \mathrm{~cm}$ i $12,5 \mathrm{~cm}$ provedena je primjenom tehnike kontaktnog kuta s kapljevinama poznatih vrijednosti slobodne površinske energije te primjenom brze tehnike ispitivanja pomoću flomastera koji sadrže tinte odgovarajućih površinskih energija.
Na slici 4 dan je prikaz primjera kapljica testnih kapljevina vode, formamida i dijodometana na površini pločice polipropilena $(\mathrm{AU})$ prije i nakon obrade plamenom (1AU, 2AU). Vidljivo je da obrada plamenom utječe na oblik kapi i kontaktni kut svih testnih kapljevina na površini uzorka AU. Jednake promjene uočene su i kod uzoraka BU - DU.

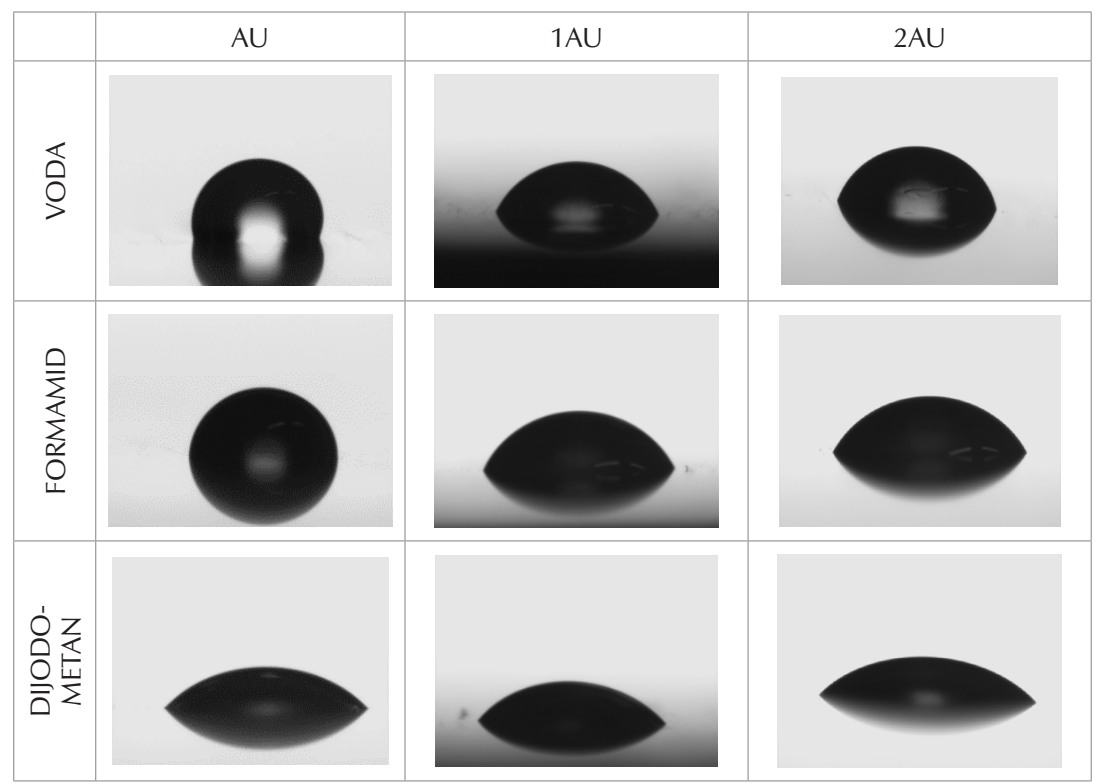

Slika 4 - Kapljica vode, formamida i dijodometana na površini uzoraka prije obrade plamenom $(\mathrm{AU})$, te nakon obrade plamenom na udaljenosti $7,5 \mathrm{~cm}$ (1AU) i $12,5 \mathrm{~cm}(2 \mathrm{AU})$

Fig. 4 - Water, formamide, and diiodomethane droplets on the sample surface before flame treatment (AU), and after flame treatment at a distance of $7.5 \mathrm{~cm}(1 \mathrm{AU})$ and $12.5 \mathrm{~cm}(2 \mathrm{AU})$ 
Eksperimentalno dobivene vrijednosti kontaktnih kutova prikazane su u tablici 7 .

Tablica 7 - Vrijednosti kontaktnih kutova prije i 1 h nakon obrade plamenom na udaljenosti od $7,5 \mathrm{~cm}$ i $12,5 \mathrm{~cm}$

Table 7 - Contact angle values before and $1 \mathrm{~h}$ after flame treatment at a distance of $7.5 \mathrm{~cm}$ and $12.5 \mathrm{~cm}$

\begin{tabular}{|c|c|c|c|}
\hline \multirow{2}{*}{$\begin{array}{l}\text { Uzorak } \\
\text { Sample }\end{array}$} & \multicolumn{3}{|c|}{$\begin{array}{l}\text { Kontaktni kut }(\theta) /{ }^{\circ} \\
\text { Contact angle }(\theta) /^{\circ}\end{array}$} \\
\hline & $\begin{array}{l}\text { Voda } \\
\text { Water }\end{array}$ & $\begin{array}{l}\text { Formamid } \\
\text { Formamide }\end{array}$ & $\begin{array}{l}\text { Dijodometan } \\
\text { Diiodomethane }\end{array}$ \\
\hline $\mathrm{AU}$ & $96,7 \pm 1,8$ & $90,1 \pm 1,2$ & $50,5 \pm 2,9$ \\
\hline $1 \mathrm{AU}$ & $57,2 \pm 7,8$ & $64,1 \pm 3,2$ & $48,1 \pm 2,8$ \\
\hline $2 \mathrm{AU}$ & $71,4 \pm 1,9$ & $61,9 \pm 1,7$ & $41,9 \pm 1,4$ \\
\hline $\mathrm{BU}$ & $92,2 \pm 2,1$ & $85,6 \pm 0,1$ & $53,5 \pm 1,2$ \\
\hline $1 \mathrm{BU}$ & $57,5 \pm 4,6$ & $71,0 \pm 0,2$ & $43,8 \pm 1,1$ \\
\hline $2 \mathrm{BU}$ & $65,9 \pm 3,9$ & $67,7 \pm 1,8$ & $45,9 \pm 0,8$ \\
\hline $\mathrm{CU}$ & $87,5 \pm 1,4$ & $82,5 \pm 2,2$ & $54,9 \pm 2,4$ \\
\hline $1 \mathrm{CU}$ & $60,1 \pm 3,4$ & $69,3 \pm 2,1$ & $47,3 \pm 0,8$ \\
\hline $2 \mathrm{CU}$ & $44,3 \pm 7,1$ & $62,8 \pm 2,5$ & $39,3 \pm 2,4$ \\
\hline DU & $93,6 \pm 1,6$ & $83,6 \pm 1,8$ & $55,5 \pm 1,6$ \\
\hline 1DU & $62,1 \pm 4,1$ & $69,9 \pm 2,0$ & $45,2 \pm 2,5$ \\
\hline 2DU & $62,5 \pm 2,8$ & $63,6 \pm 1,4$ & $43,8 \pm 1,1$ \\
\hline
\end{tabular}

Visoke vrijednosti kontaktnog kuta s vodom na uzorcima $\mathrm{AU}, \mathrm{BU}, \mathrm{CU}$ i DU ukazuju na visoku hidrofobnost i nepolarnu prirodu površine. AU uzorak, bez punila, je najhidrofobniji, dok niže vrijednosti kontaktnog kuta s vodom za uzorke BU, CU i DU ukazuju na manju hidrofobnost površine, što je posljedica dodatka punila polarnog karaktera. U odnosu na uzorak AU vrijednosti kontaktnog kuta s vodom za BU, CU i DU niže su za 3 - $9^{\circ}$.

Nakon obrade plamenom vidljive su znatne promjene kontaktnog kuta s vodom, formamidom i dijodometanom (tablica 7), što upućuje na to da obrada rezultira promjenama na površini uzoraka. Da bi se analizirale te promjene iz eksperimentalno određenih vrijednosti kontaktnih kutova primjenom modela harmonijske sredine $(W u)$ (jedn. 2), određene su vrijednosti disperzne i polarne komponente te vrijednosti ukupne slobodne površinske energije ispitivanih uzoraka (tablica 8 ).

Vrijednosti površinske energije neobrađenih uzoraka male su i kreću se od 29,6 do 32,9 mJ m² (tablica 8). Uzorak bez punila AU ima sličnu vrijednost ukupne slobodne površinske energije kao i ostali neobrađeni uzorci, ali je vrijednost polarne komponente $0 \mathrm{~mJ} \mathrm{~m}{ }^{-2}$, dakle nepolarnog je karaktera, dok uzorci s punilom (BU, CU, DU) imaju određenu vrijednost polarne komponente. Iz rezultata je vidljivo da se obradom površine svih uzoraka plamenom, bez obzira na udaljenost plamena od uzorka, slobodna površinska energija znatno povećava, i to zbog povećanja polarne komponente za 10 do $18 \mathrm{~mJ} \mathrm{~m}$-2, ovisno o uzorku i o udaljenosti plamena tijekom obrade. Iz dobivenih rezultata ne može se jednoznačno zaključiti o učinku udaljenosti plamena od površine uzorka. Za uzorke AU i BU bolji učinak odnosno veće povećanje polarne komponente do-

Tablica 8 - Vrijednosti slobodnih površinskih energija prije i nakon obrade plamenom na udaljenosti od 7,5 cm i $12,5 \mathrm{~cm}$ proračunate prema Wuovom modelu

Table 8 - Surface free energy values of samples before and after flame treatment at a distance of $7.5 \mathrm{~cm}$ and $12.5 \mathrm{~cm}$ calculated according to Wu's model

\begin{tabular}{|c|c|c|c|c|c|c|c|}
\hline \multirow[t]{2}{*}{$\begin{array}{l}\text { Uzorak } \\
\text { Sample }\end{array}$} & \multirow[t]{2}{*}{$\begin{array}{l}\text { Flomaster } 38-50 \\
\text { Test pen } 38-50 / \mathrm{mJ} \mathrm{m}^{-2}\end{array}$} & \multicolumn{3}{|c|}{$\begin{array}{c}1 \mathrm{~h} \text { nakon obrade } \\
1 \mathrm{~h} \text { after treatment } \\
\mathrm{\gamma} / \mathrm{mJ} \mathrm{m} \mathrm{m}^{-2}\end{array}$} & \multicolumn{3}{|c|}{$\begin{array}{c}24 \mathrm{~h} \text { nakon obrade } \\
24 \mathrm{~h} \text { after treatment } \\
\gamma / \mathrm{mJ} \mathrm{m} \mathrm{m}^{-2}\end{array}$} \\
\hline & & $\gamma_{s}^{d}$ & $\gamma_{\mathrm{s}}^{\mathrm{p}}$ & $\gamma_{\mathrm{s}}$ & $\gamma_{s}^{d}$ & $\gamma_{s}^{p}$ & $\gamma_{\mathrm{s}}$ \\
\hline $\mathrm{AU}$ & $<38$ & 32,0 & 0,0 & 32,0 & 32,0 & 0,0 & 32,0 \\
\hline $1 \mathrm{AU}$ & $40 / 42$ & 28,5 & 18,1 & 46,6 & 28,7 & 11,0 & 39,8 \\
\hline $2 \mathrm{AU}$ & $42 / 44$ & 33,7 & 10,4 & 44,1 & 32,3 & 8,4 & 40,7 \\
\hline $\mathrm{BU}$ & $<38$ & 30,1 & 2,1 & 32,2 & 30,1 & 2,1 & 32,2 \\
\hline $1 \mathrm{BU}$ & 42 & 28,4 & 16,6 & 44,9 & 28,1 & 9,6 & 37,8 \\
\hline $2 \mathrm{BU}$ & $38 / 40$ & 30,1 & 13,0 & 43,1 & 30,1 & 9,7 & 39,9 \\
\hline $\mathrm{CU}$ & $<38$ & 28,8 & 4,1 & 32,9 & 28,8 & 4,08 & 32,9 \\
\hline $1 \mathrm{CU}$ & 40 & 28,2 & 16,1 & 44,3 & 29,1 & 10,9 & 40,0 \\
\hline $2 \mathrm{CU}$ & 46 & 29,6 & 23,4 & 53,0 & 30,5 & 12,7 & 43,2 \\
\hline DU & $<38$ & 26,0 & 3,7 & 29,6 & 26,0 & 3,7 & 29,6 \\
\hline $1 \mathrm{DU}$ & 40 & 29,2 & 14,6 & 43,8 & 29,4 & 10,4 & 39,8 \\
\hline 2DU & 46 & 31,0 & 14,7 & 45,6 & 29,9 & 12,1 & 42,0 \\
\hline
\end{tabular}

$\gamma_{s}^{d}$ - disperzna komponenta, $\gamma_{s}^{p}-$ polarna komponenta, $\gamma_{s}-$ ukupna slobodna površinska energija 
biveno je za udaljenost plamena $7,5 \mathrm{~cm}$, za uzorak $\mathrm{CU}$ na udaljenosti $12,5 \mathrm{~cm}$, dok za DU uzorak udaljenost nema učinak na porast polarne komponente. Međutim, važno je uočiti da svi uzorci obrađeni plamenom imaju vrijednost slobodne površinske energije veće od $40 \mathrm{~mJ} \mathrm{~m}{ }^{-2}$ koliko je potrebno za daljnje procesuiranje bojenjem. ${ }^{15}$

Brza analiza površinske energije koja se uobičajeno primjenjuje $u$ industriji provedena je primjenom flomastera koji sadrže tinte odgovarajućih površinskih energija od 38 do $50 \mathrm{~mJ} \mathrm{~m} \mathrm{~m}^{-2}$. Rezultati neobrađenih uzoraka (AU - DU) ukazuju na površinsku energiju manju od $38 \mathrm{~mJ} \mathrm{~m}^{-2}$, dok se vrijednosti površinskih energija dobivene nakon obrade plamenom na udaljenosti $7,5 \mathrm{~cm}(1 \mathrm{AU}-1 \mathrm{DU})$ povećavaju na $40-42 \mathrm{~mJ} \mathrm{~m}{ }^{-2}$, odnosno na udaljenosti $12,5 \mathrm{~cm}$ na $42-46 \mathrm{~mJ} \mathrm{~m}^{-2}(2 \mathrm{AU}, 2 \mathrm{CU}$ i 2DU) izuzev uzorka 2BU kod kojeg je dobivena vrijednost $38 / 40 \mathrm{~mJ} \mathrm{~m}^{-2}$ (tablica 8). lako ispitivanja flomasterom pokazuju povećanje površinske energije nakon obrade, vrijednosti se uglavnom razlikuju od vrijednosti dobivenih mjerenjem kontaktnog kuta. Ta metoda temelji se na vlaženju površine tintom (kapljevinom), pri čemu nije moguće dobiti informaciju o polarnosti površine, što je ključno za procjenu adhezije na međupovršini.

Slobodna površinska energija određena je i nakon $24 \mathrm{~h}$ da bi se utvrdilo dolazi li do promjene aktivnosti površine tijekom vremena (tablica 8). Vrijednost polarne komponente $\gamma_{s}{ }^{p}$ znatno se smanjuje u 24 satnom razdoblju nakon obrade plamenom, dok se vrijednost disperzne komponente $\gamma_{s}{ }^{d}$ ne mijenja znatnije. $\gamma_{\mathrm{s}}^{\mathrm{p}}$ kod uzoraka obrađenih na udaljenosti od 7,5 cm nakon stajanja $24 \mathrm{~h}$ smanjuje se za $28 \%-42 \%$, a kod udaljenosti od $12,5 \mathrm{~cm}$ za $18 \%$ - $46 \%$ (tablica 8). Kao rezultat smanjenja polarne komponente smanjuje se i vrijednost ukupne površinske energije $\left(\gamma_{\mathrm{s}}\right)$. Smanjenje slobodne površinske energije $s$ vremenom uočeno je i za materijale koji su modificirani korona obradom. ${ }^{15,16}$ Taj učinak pripisuje se međusobnim reakcijama kemijskih skupina na obrađenoj površini, oksidacijskim reakcijama tijekom izlaganja na zraku i migracijom aditiva iz mase materijala na površinu. $12,5 \mathrm{~cm}$

\subsection{Mikroskopska analiza površine}

$S$ namjerom da se utvrde promjene morfologije površine uzoraka prije i nakon obrade plamenom, provedena je analiza primjenom pretražnog elektronskog mikroskopa (slika 5).

SEM analizom utvrđene su značajne razlike morfologije uzoraka prije i nakon obrade plamenom. Površina svih uzoraka prije obrade plamenom je hrapava uz prisutnost brojnih sitnih šupljina. Nakon obrade plamenom na udaljenosti od 7,5 cm uzorka AU uočavaju se izrazite promjene na površini vidljive kao sitne točkaste rupice i izrazite brojne dublje brazde. Kod uzorka 2AU obrađenog na udaljenosti plamena od $12,5 \mathrm{~cm}$ također se uočava točkasta
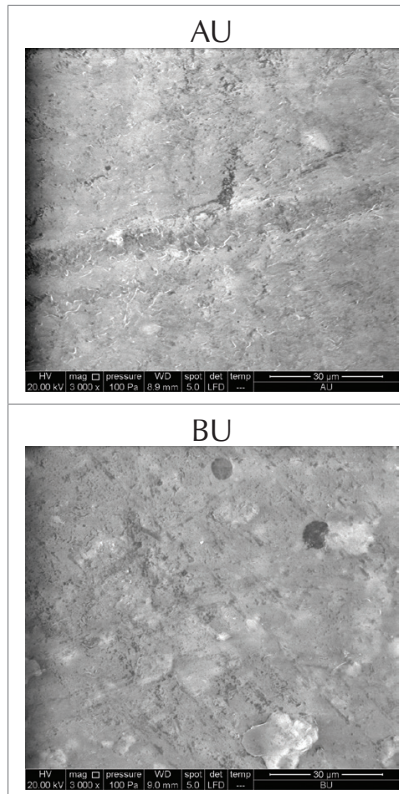

$\mathrm{CU}$

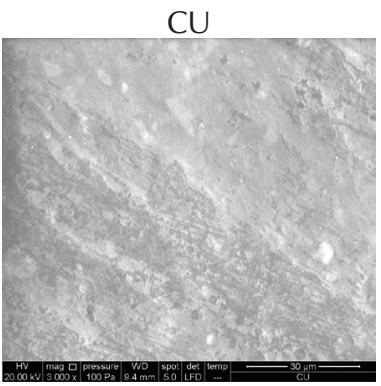

DU

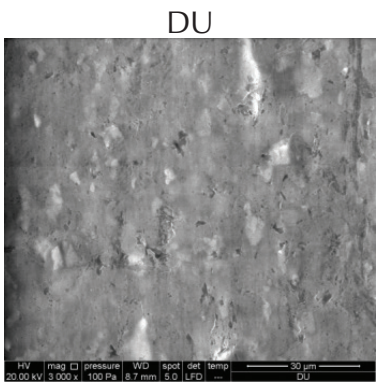

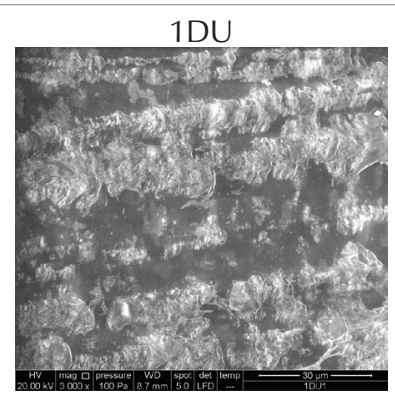

$1 \mathrm{AU}$

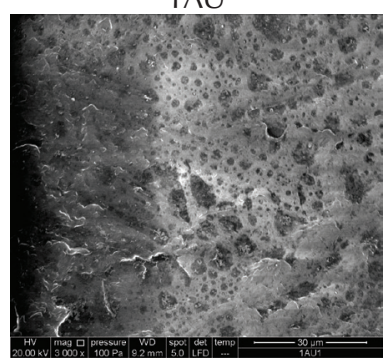

$1 \mathrm{BU}$

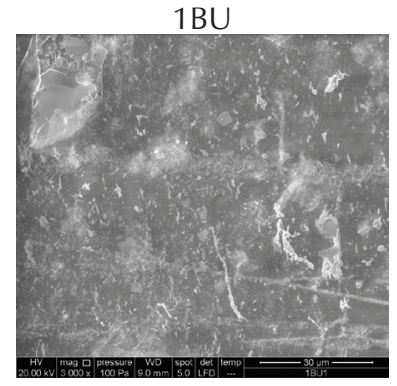

$1 \mathrm{CU}$
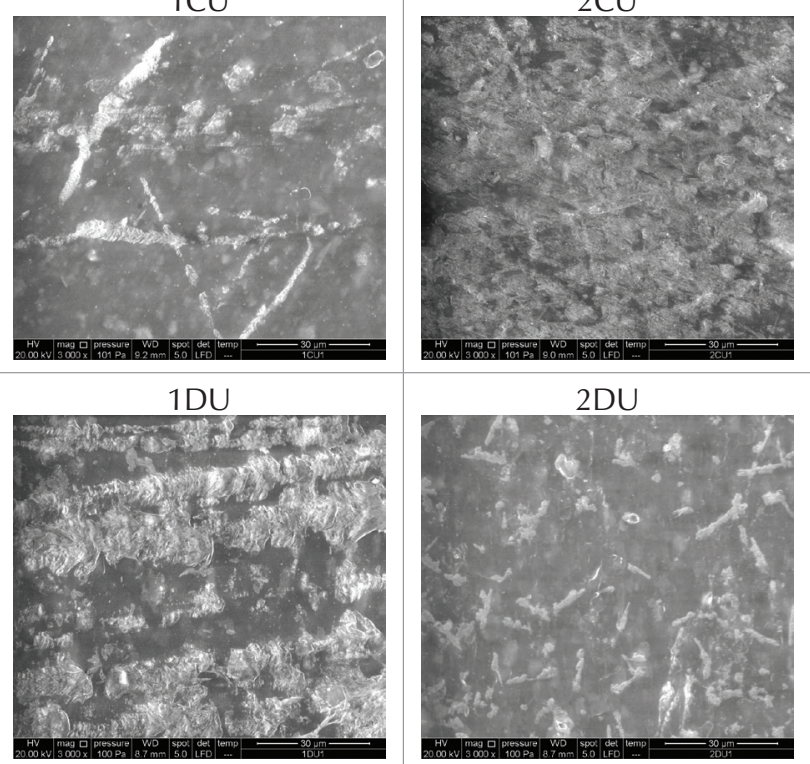

Slika 5 - SEM mikrografije uzoraka prije i nakon obrade plamenom na udaljenosti $7,5 \mathrm{~cm}$ i

Fig. 5 - SEM micrographs of samples before and after flame treatment at the distance of 7.5 $\mathrm{cm}$ and $12.5 \mathrm{~cm}$ 
struktura nastala obradom. Istraživanje Medeiros i suradnika također je pokazalo veliku poroznost neobrađenog PP, a nakon obrade plamenom površina PP je homogenija. ${ }^{3}$ Nakon obrade plamenom na udaljenosti 7,5 cm uzoraka BU - DU površina je homogenija, nešto manje hrapavosti, ali vidljive mreže tankih linija koje su posljedica obrade plamenom. Nakon obrade plamenom tih uzoraka na udaljenosti od 12,5 cm u odnosu na obradu 7,5 cm vidljiva je pojava znatno gušće mreže tankih linija nastalih obradom.

\subsection{Rezultati ispitivanja adhezije}

Rezultati ispitivanja adhezije premaza zarezivanjem mrežice kod svih obojenih uzoraka zadovoljavajućih su svojstava, odnosno nakon uklanjanja ljepljive trake nema vidljivog odvajanja premaza od supstrata (slika 6). Dobiveni rezultati jasno ukazuju na dobru adheziju na međupovršini supstrat/osnovni premaz te prema normi ISO 2409 spadaju u kategoriju 0, koja karakterizira izvrsnu adheziju.

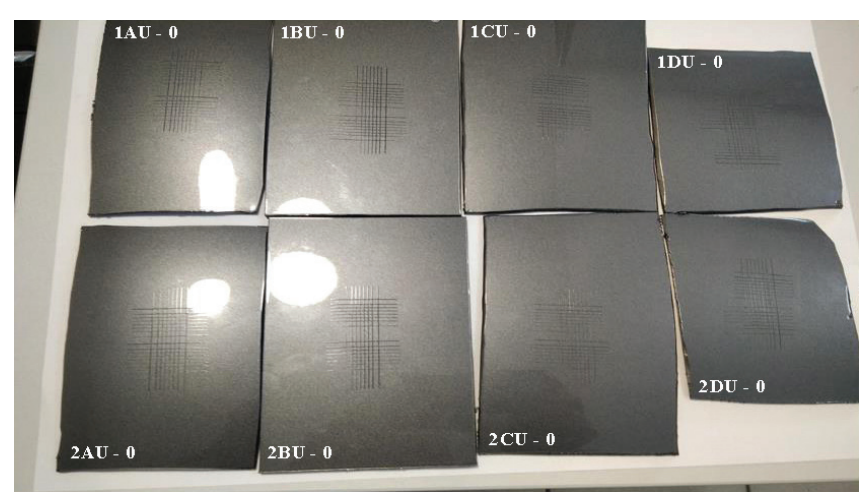

Slika 6 - Obojeni uzorci nakon ispitivanja zarezivanjem mrežice Fig. 6 - Dyed samples after the cross cut test

Rezultati ispitivanja pranjem pod visokim tlakom za sve obojene uzorke zadovoljavajući su i karakterizirani su ocjenom 0 (slika 7). Nakon PVT ispitivanja nema vidlji-

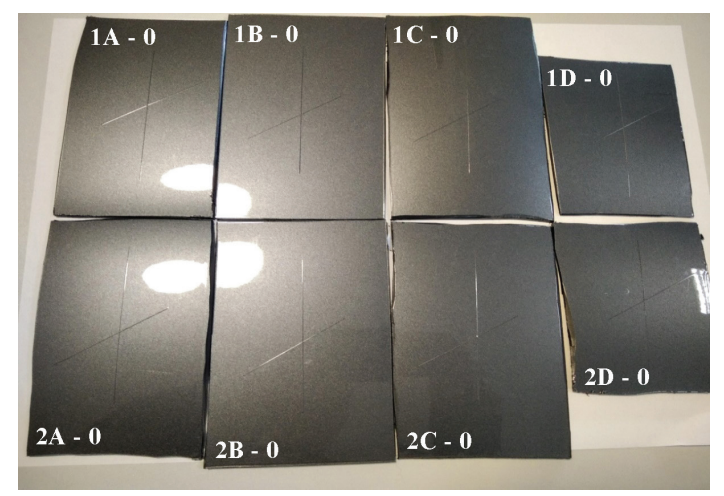

Slika 7 - Obojeni uzorci nakon ispitivanja pranja pod visokim tlakom PVT

Fig. 7 - Dyed samples after high pressure PVT washing test vih oštećenja, odnosno odvajanja osnovnog sloja boje od supstrata te prema normi ISO 16925 spadaju u klasu 0, prihvatljivo. Dobiveni rezultati jasno ukazuju na izvrsnu adheziju na međupovršini supstrat/osnovni premaz čak i pri vrlo zahtjevnim uvjetima ispitivanja proizvoda automobilske industrije.

Dobiveni rezultati dobre adhezije premaza s uzorcima obrađenim plamenom na $7,5 \mathrm{~cm}$ i $12,5 \mathrm{~cm}$ prema oba provedena ispitivanja posljedica su znatnog povećanja polarne komponente odnosno ukupne slobodne površinske energije iznad $40 \mathrm{~mJ} \mathrm{~m}^{-2}$, što je dostatno za ostvarivanje dobre adhezije. ${ }^{15}$

\section{Zaključak}

Termogravimetrijskom analizom utvrđeno je da se razgradnja čistog polipropilena (AU) odvija pri nižim temperaturama u odnosu na uzorke BU - DU koji sadrže punilo talk i čađu. Entalpija taljenja se nakon obrade plamenom ne mijenja ili se mijenja neznatno, ovisno o vrsti uzorka i udaljenosti plamena. Temperatura taljenja se ne mijenja, te se stoga može zaključiti da proces obrade plamenom nema utjecaja na kristalnu strukturu. Obradom plamenom, u definiranim industrijskim uvjetima, ostvarena je promjena kemijskog sastava površinskog sloja uzoraka nastankom polarnih skupina na bazi kisika (karbonilna, hidroksilna, karboksilna). Vrijednosti površinskih energija nakon obrade plamenom porasle su za oko $33 \%$. Nisu utvrđene znatne razlike slobodnih površinskih energija između uzoraka obrađenih na udaljenost plamena $7,5 \mathrm{~cm}$ i 12,5 cm. Rezultati ispitivanja površinske energije flomasterom također ukazuju na povećanje slobodne površinske energije nakon obrade plamenom. Utvrđeno je da se $24 \mathrm{~h}$ nakon obrade vrijednost polarne komponente, a time i ukupne površinske energije smanjuje. Uz nastalu toplinsku oksidaciju površine, pri visokim temperaturama plamena, došlo je i do morfološke promjene na samoj površini. Primjenom normi ISO 2409 i ISO 16925/D25 2018-B koje se primjenjuju za ispitivanje adhezije, potvrđena je izvrsna adhezija na međupovršini supstrat/premaz u proizvodima automobilske industrije.

\section{Popis kratica i simbola List of abbreviations and symbols}

PP - polipropilen

- polypropylene

TPO

- termoplastični poliolefin

- thermoplastic polyolefin

DSC - diferencijalna pretražna kalorimetrija

- differential scanning calorimetry

TGA - termogravimetrijska analiza

- thermogravimetric analysis

DTG - diferencijalna termogravimetrijska analiza - differential thermogravimetric analysis 
ATR - FTIR - Prigušena totalna refleksija - Infracrvena spektroskopija s Fourierovom transformacijom signala

- Attenuated total reflection - Fourier-transform infrared spectroscopy

SEM - pretražna elektronska mikroskopija

- scanning electron microscopy

$T_{5} \quad$ - temperatura pri $5 \%$ gubitka mase, ${ }^{\circ} \mathrm{C}$

- temperature at $5 \%$ of mass loss, ${ }^{\circ} \mathrm{C}$

$T_{50} \quad$ - temperatura pri $50 \%$ gubitka mase, ${ }^{\circ} \mathrm{C}$

- temperature at $50 \%$ of mass loss, ${ }^{\circ} \mathrm{C}$

$T_{\text {end set }} \quad$ - temperatura maksimalnog gubitka mase, ${ }^{\circ} \mathrm{C}$

- temperature of maximal mass loss, ${ }^{\circ} \mathrm{C}$

$T_{\max } \quad$ - temperatura maksimalne brzine razgradnje, ${ }^{\circ} \mathrm{C}$

- temperature of maximal degradation rate, ${ }^{\circ} \mathrm{C}$

$\Delta T \quad$ - temperaturni raspon razgradnje $\left(T_{\text {end set }}-T_{5}\right),{ }^{\circ} \mathrm{C}$

- temperature range of degradation $\left(T_{\text {end set }}-T_{5}\right),{ }^{\circ} \mathrm{C}$

$T_{\mathrm{m}} \quad-$ talište, ${ }^{\circ} \mathrm{C}$

- melting temperature, ${ }^{\circ} \mathrm{C}$

$\Delta H_{\mathrm{m}} \quad-$ entalpija taljenja, $\mathrm{Jg}^{-1}$

- melting enthalpy, $\mathrm{Jg}^{-1}$

$\gamma^{d} \quad-$ disperzna komponenta

slobodne površinske energije, $\mathrm{mJ} \mathrm{\textrm {m } ^ { - 2 }}$

- dispersive component of surface free energy, $\mathrm{mJ} \mathrm{m} \mathrm{m}^{-2}$

$\gamma^{p} \quad$ - polarna komponenta

slobodne površinske energije, $\mathrm{mJ} \mathrm{m}^{-2}$

- polar component of surface free energy, $\mathrm{mJ} \mathrm{m}^{-2}$

$\gamma_{s}$

- ukupna slobodna površinska energija, $\mathrm{mJ} \mathrm{m}^{-2}$

- total surface free energy, $\mathrm{mJ} \mathrm{m} \mathrm{m}^{-2}$

\section{Literatura \\ References}

1. N. Encinas, B. Díaz-Benito, J. Abenojar, A. M. Martinez, Extreme durability of wettability changes on polyolefin surfaces by atmospheric pressure plasma torch, Surf. Coat. Technol. 205 (2010) 396-402, doi: https://doi.org/10.1016/j.surfcoat.2010.06.069.

2. W. Urbaniak-Domagala, Pre-treatment of Polypropylene Films for the Creation of Thin Polymer Layers, Part 1: The Use of Chemical, Electrochemical, and UV Methods, J. Appl. Polym. Sci. 122 (2011) 2071-2080, doi: https://doi. org/10.1002/app.34301.

3. E. Medeiros, R. Brandes., H. Ali Al-Qureshi, D. de O. S. Recouvreux, Effect of flame treatment in the coating adhesion on polypropylene substrate, $24^{\text {th }} \mathrm{ABCM}$ International Congress of Mechanical Engineering, December 3-8, (2017) Cu- ritiba, PR, Brazil, 1-7, doi: https://doi.org/10.26678/ABCM. COBEM2017.COB17-0489.

4. S. Waddington, D. Briggs, Adhesion mechanisms between polymer coatings and polypropylene studied by X.p.s. and SIMS, Polym. commun. 32 (16) (1991) 506-508.

5. F. Awaja, M., Gilber, G. Kelly, B. Fox, P. J. Pigram, Adhesion of polymers, Prog. Polym. Sci. 34 (2009) 948-968, doi: https:// doi.org/10.1016/j.progpolymsci.2009.04.007.

6. S. Farris, S. Pozzoli, P. Biagioni, L. Duó, S. Mancinelli, The fundamentals of flame treatment for the surface activation of polyolefin polymers - A review, Polymer 51 (2010) 35913605, doi: https://doi.org/10.1016/j.polymer.2010.05.036.

7. $S$. $W u$, Polar and non-polar interactions in adhesion, J. Adhes. 5 (1973) 39-55, doi: https://doi. org/10.1080/00218467308078437.

8. R. J. Good, Contact angle, wetting, and adhesion: A critical review, u K. L. Mittal (ur.) Contact Angle, Wettability and Adhesion, VSP, Utrecht, 1993, str. 3-36.

9. Paints and Varnishes - Cross-cut test, ISO 2409:2007 E.

10. Paint and Varnishes - Determination of the Resistance of Coating to Pressure Water-Jetting, ISO 16925:2014.

11. J. D. Peterson, S. Vyazovkin, C. A. Wight, Kinetics of the thermal and thermo-oxidative degradation of polystyrene, polyethylene and poly(propylene), Macromol. Chem. Phys. 202 (2001) 775-784, doi: https://doi. org/10.1002/1521-3935(20010301)202:6\%3C775::AIDMACP775\%3E3.0.CO;2-G.

12. S. Pavlidou, C. D. Papaspyrides, A review on polymer - layered silicate nanocomposites, Prog. Polym. Sci. 33 (2008) 1119-1198, doi: https://doi.org/10.1016/j.progpolymsci.2008.07.008.

13. W.Urbaniak-Domagala, The Use of the Spectrometric Technique FTIR-ATR to Examine the Polymers Surface, u M. Akhyar Farrukh (ur.) Advanced Aspects of Spectroscopy, InTech, Rijeka, 2012, str. 85-104, doi: https://doi.org/10.5772/2757.

14. P. Pagès, Characterization of polymer materials using FT-IR and DSC Techniques, u R. Artiaga Díaz (ur.), Thermal analysis. Fundamentals and applications to material characterization, Universidade da Coruna, 2005., str. 121-140.

15. C. Q. Sun, D. Zhang, L. C. Wadsworth, Corona Treatment of Polyolefin Films - A Review, Adv. Polym. Technol. 18 (1999) 171-180, 1999, doi: https://doi.org/10.1002/(SICI)1098-23 29(199922)18:2\%3C171::AID-ADV6\%3E3.0.CO;2-8

16. URL: https://sareltech.com/wp-content/uploads/2019/04/ Corona-Treatment-of-PP-Cast-films.pdf (15. 10. 2020.).

\section{ZAHVALA}

Istraživanje je provedeno kao sastavni dio projekta "Pilot linija bojenja za eksperimentalna istraživanja, razvoj i inovacije" sufinanciranog od Europske unije iz Europskog fonda za regionalni razvoj. 


\section{SUMMARY}

\section{Influence of Thermoplastic Polyolefins Flame Treatment on Coating Adhesion in Industrial Conditions of Robotic Dyeing \\ Vlado Merzel, ${ }^{a}$ Sanja Lučić Blagojević, ${ }^{b}$ Zrinka Buhin Šturlić, ${ }^{b}$ Mario Meheš, and Mirela Leskovac ${ }^{b^{*}}$}

In this paper, the influence of flame treatment on the surface properties of polypropylene (PP) and thermoplastic polyolefins with talc and carbon black filler (TPO), and adhesion of the applied coating in the conditions of industrial robotic dyeing process were investigated. The flame treatment was carried out at two distances from the flame $(7.5 \mathrm{~cm}$ and $12.5 \mathrm{~cm})$ at constant air and methane flows as well as speed of the burner. The thermal stability of untreated samples was investigated using thermogravimetric analysis (TCA). The change in thermal properties before and after flame treatment was investigated using differential scanning calorimetry (DSC). Changes of the samples' surface energy were examined before flame treatment, $1 \mathrm{~h}$ and $24 \mathrm{~h}$ after flame treatment, by the contact angle method. Qualitative analysis of the surface chemical composition, before and after flame treatment, was performed by ATR - FTIR analysis, and morphological changes by scanning electron microscopy (SEM). After applying the base layer, dye and topcoat on the surface of the treated samples, the adhesion was determined by standard methods ISO 2409 and ISO 16925/D25 2018-B. The results showed that TPO containing talc and carbon black filler have better thermal stability compared to PP. Flame treatment influenced the surface characteristics of the samples, namely the increase in surface free energy and the appearance/structure of the surface. With ATR - FTIR, the existence of polar groups on the surface after flame treatment were determined. According to the standards, all dyed samples met the requirements of excellent adhesion on the substrate/coating interface.

\section{Keywords}

Polypropylene, thermoplastic polyolefins, flame treatment, surface free energy, coating, adhesion

a AD PLASTIK d. d., Solin, PJ Zagreb, Croatia

${ }^{\mathrm{b}}$ University of Zagreb, Faculty of Chemical Engineering and Technology Marulićev trg 19, 10000 Zagreb, Croatia
Original scientific paper Received November 4, 2020 Accepted February 7, 2021 